\title{
RANCANG BANGUN SISTEM PELAPORAN PELANGGARAN PARKIR BERBASIS ANDROID
}

\author{
Irvan Dinda Prakoso ${ }^{1}$, Made Sudarma ${ }^{2}$, I Made Arsa Suyadnya ${ }^{3}$ \\ Program Studi Teknik Elektro, Fakultas Teknik, Universitas Udayana \\ Email: irvandindaprakoso@gmail.com ${ }^{1}, \underline{\text { msudarma@unud.ac.id }}{ }^{2}$, arsa.suyadnya@unud.ac.id ${ }^{3}$
}

\begin{abstract}
Abstrak
Tingkat kepemilikan kendaraan pribadi yang tinggi akan menimbulkan kebutuhan lahan parkir yang besar pada zona tertentu. Tidak semua tempat mampu untuk menyediakan lahan parkir yang mencukupi, sehingga badan jalan yang berada disekitarnya digunakan untuk lahan parkir. Hal tersebut akan menimbulkan permasalahan lalu lintas. Pemanfaatan teknologi informasi dapat menjadi salah satu solusi untuk mengatasi permasalahan tersebut. Tujuan dari penelitian ini adalah merancang dan membangun sistem pelaporan pelanggaran parkir berbasis Android sehingga masyarakat dapat turut andil untuk melaporkan pelanggaran dalam bentuk foto yang langsung dikirim pada server DLLAJ (Dinas Lalu Lintas Angkutan Jalan) dan mempermudah petugas dalam penangannya. Rancangan pemodelan sistem meliputi Use Case Diagram, Activity Diagram dan struktur database. Proses dari aplikasi ini yaitu mengirimkan foto pelanggaran parkir ke server, kemudian mengekstraksi foto tersebut untuk mendapatkan metadata (latitude dan longitude) yang menunjukkan lokasi pelanggaran tersebut terjadi. Berdasarkan hasil pengujian aplikasi dengan metode Black Box Testing, keseluruhan fungsionalitas aplikasi telah dinyatakan berhasil. Selain itu, berdasarkan hasil pengujian System Usability Scale (SUS), didapatkan skor 79,5 yang berarti nilai berada di atas rata-rata sehingga aplikasi dapat diterima oleh pengguna.

Kata Kunci : Pengaduan Masyarakat, Pelaporan Pelanggaran Parkir, Sistem Pelaporan.
\end{abstract}

\begin{abstract}
The high level of ownership of private vehicles will require large parking lots in certain zones. Not all places are able to provide sufficient parking space, so that the road body around it is used for parking lots. This will cause traffic problems. Utilization of technology can be one solution to overcome these problems. The purpose of this research is to design and build an Android-based parking violation reporting system so that the community can take part in reporting violations in the form of photos that are directly sent to the DLLAJ server (Road Transport Traffic Service) and make it easier for officers in their handling. System modeling plans include the Use Case Diagram, Activity Diagram and database structure. The process of this application is to send a parking violation photo to the server, then extract the photo to get the metadata (latitude and longitude) that shows the location of the violation. Based on the results of testing the application with the Black Box Testing method, the overall functionality of the application has been declared successful. In addition, based on the results of the System Usability Scale (SUS) test, a score of 79.5 means that the value is above the average and the application can be accepted by the user.
\end{abstract}

Keywords : Public Complaints, Parking Violation Reporting, Reporting System.

\section{PENDAHULUAN}

Teknologi informasi dan komunikasi berkembang sangat pesat, berbagai kemudahan dapat dirasakan dengan adanya perkembangan teknologi, salah satunya adalah penerapan teknologi informasi pada bidang pemerintahan [1]. Pada awalnya penerapan teknologi informasi pada bidang pemerintahan di Indonesia kurang populer, akan tetapi semakin berkembangnya zaman 
semakin banyak gagasan baru yang mulai memanfaatkan teknologi informasi untuk berkomunikasi dengan masyarakat ataupun mendengarkan keluhan masyarakat, khususnya kemacetan lalu lintas yang disebabkan oleh parkir di bahu jalan. Kawasan ibu kota dengan kepadatan penduduk dan tingkat perekonomian yang tinggi menyebabkan tingginya keinginan masyarakat untuk memiliki kendaraan pribadi [2]. Jika kondisi ini tidak diperhatikan oleh pemerintah dalam manajemen lalu lintas yang tidak adanya batasan dalam penggunaan kendaraan pribadi, maka akan mendorong masyarakat untuk selalu menggunakan kendaraan pribadi. Hal ini akan menimbulkan dampak negatif yaitu meningkatnya kebutuhan lahan parkir yang besar pada area-area tertentu. Tidak semua tempat sanggup untuk menyediakan lahan parkir yang mencukupi, sehingga bahu jalan disekitar area tersebut dimanfaatkan untuk lahan parkir. Apabila jalan tersebut dilalui lalu lintas dalam jumlah yang besar maka dapat dipastikan bahwa parkir di bahu jalan akan menyebabkan permasalahan lalu lintas.

Usaha yang telah dilakukan untuk memecahkan permasalahan tersebut seperti memberikan rambu-rambu larangan parkir sampai dengan sanksi berupa kurungan paling lama 1 bulan atau denda paling banyak Rp.250.000,00 [3]. Namun usaha ini belum maksimal, hal ini disebabkan karena dalam penerapannya untuk memantau pengendara yang melanggar parkir masih dilakukan secara manual dimana petugas harus berjaga di tempat tersebut agar tidak parkir sembarangan.

Dalam mengatasi masalah tersebut, dibutuhkan sistem pelaporan yang nantinya dapat menampung keluhan masyarakat terkait pelanggaran parkir di bahu jalan. Sistem pelaporan atau sistem pengaduan masyarakat dapat memanfaatkan teknologi informasi berbasis website dan mobile seperti yang dilakukan oleh [4]. Penelitian tersebut merancang dan membangun sistem pelaporan kerusakan jalan pada Bina Marga Makasar Berbasis web dan mobile sehingga laporan yang dilengkapi dengan foto langsung dapat di kirim ke website dan petugas dapat menampilkan langsung laporan yang telah diterima. Pada penelitian ini sistem dapat memudahkan dalam pengolahan data dan pemetaan laporan menggunakan maps. Penelitian lainnya [5] merancang sebuah sistem pelayanan pengaduan masyarakat berbasis Web, dimana di dalam website ini masyarakat dapat mengisi langsung form pengaduan.

Dari beberapa penelitian yang telah dilakukan di atas terdapat beberapa kasus mengenai pengaduan/pelaporan masyarakat yaitu pelaporan pelanggaran parkir. Penelitian ini akan merancang sebuah sistem yang dapat menampung laporan masyarakat mengenai pelanggaran parkir di bahu jalan melalui aplikasi berbasis Android. Dari aplikasi ini masyarakat dapat berkontribusi untuk melaporkan para pengendara yang melakukan pelanggaran parkir di bahu jalan. Pengguna aplikasi dapat melakukan pengambilan beberapa gambar kendaraan dan meng-inputkan plat nomor kendaraan yang melanggar. Kemudian gambar tersebut dikirim ke sebuah website yang menampilkan data-data pelanggaran yang terjadi dan dengan memanfaatkan Google Maps API, website tersebut dapat memvisualisasi peta digital untuk menampilkan dimana pelanggaran parkir terjadi.

\section{TINJAUAN PUSTAKA}

\subsection{Metadata}

Metadata adalah data yang mengandung informasi mengenai suatu data. Secara sederhana, metadata dapat diartikan sebagai "data tentang data". Metadata pada umumnya berisikan informasi dasar mengenai data apa, siapa dimana, kapan, mengapa serta bagaimana sumber data tersebut [7]. Contoh metadata dapat dilihat pada gambar 1.

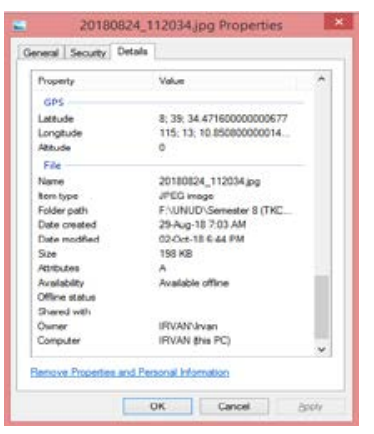


Gambar 1. Metadata dari foto 


\subsection{Google Maps API}

Google Maps adalah salah satu pengembangan teknologi Google yang dimanfaatkan untuk menanamkan Google Map pada aplikasi. Google Maps API merupakan library dalam bentuk javascript yang berguna untuk dapat memanipulasi peta atau menambahkan konten melalui jenis servis yang dimiliki oleh Google Maps sesuai dengan kebutuhan [8]. Dalam pengembangannya. Beberapa kemampuan Google Maps API yaitu untuk mendapatkan gambar peta statis, melakukan geocoding, dan memberikan petunjuk arah.. Tampilan Google Maps dapat dilihat pada gambar 2.

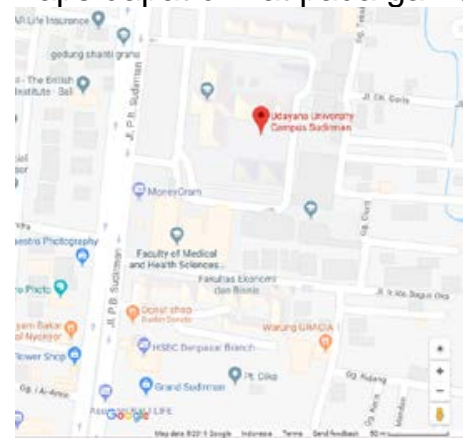

Gambar 2. Google maps

\subsection{Pengujian Black Box}

Pengujian yang dilakukan yaitu untuk mengetahui apakah seluruh fungsionalitas sistem sesuai dengan apa yang telah dirancang sebelumnya. Black box testing hanya menguji fungsi-fungsi yang terdapat pada sistem tanpa perlu mengetahui struktur internal kode program.

\subsection{Pengujian System Usability Scale}

System Usability Scale (SUS) adalah metode uji kegunaan sistem untuk mengetahui kualitas dari sistem tersebut dengan cara menggunakan 10 pertanyaan berbentuk kuisioner yang diikuti dengan 5 opsi jawaban untuk setiap pertanyaan, mulai dari sangat setuju hingga sangat tidak setuju [10].

Dalam mengkonversi nilai responden, setiap pertanyaan akan memiliki bobot yang berkisar dari 0 sampai 4 . Dalam hal ini, nilai dari pertanyaan bernomor ganjil akan dikurangi 1 dan nilai dari pertanyaan bernomor genap adalah 5 dikurangi dengan nilai skala yang diberikan oleh responden. Setelah itu hasil konversi dikalikan 2,5 dan dihitung rata-ratanya. Nilai pada SUS akan dianggap layak apabila nilai berada di atas 68 [10]. Penelitian [11], [12] menjabarkan nilai SUS ke dalam perbandingan range nilai seperti Gambar 3. Sesuai dengan gambar 3, misalnya nilai SUS yang diperoleh adalah 70 maka nilai berada pada grade $\mathrm{C}$, acceptable dan adjective ratings: good.

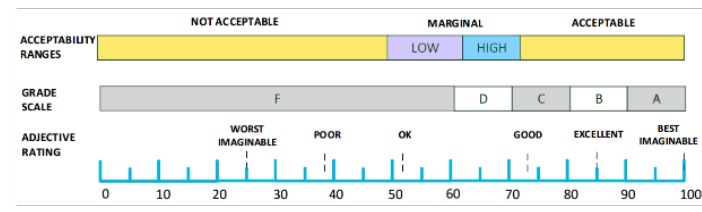

Gambar 3. Range nilai SUS

\section{METODE PENELITIAN}

\subsection{Tahapan Penelitian}

Tahapan penelitian rancang bangun sistem pelaporan pelanggaran parkir berbasis Android dilakukan dengan langkah-langkah berikut:

1. Mengidentifikasi dan merumuskan masalah.

2. Melakukan studi literatur dengan mengumpulkan data referensi serta modul-modul mengenai tools yang dapat digunakan untuk membangun aplikasi.

3. Melakukan pemodelan sistem seperti membuat Use Case Diagram, Activity Diagram skenario aplikasi dan perancangan database.

4. Membuat sistem yang dapat menampung keluhan masyarakat mengenai pelanggaran parkir.

5. Melakukan pengujian analisis hasil pengujian sistem apakah sistem sudah berjalan dengan baik menggunakan Black Box testing dan usability testing

6. Membuat hasil dan kesimpulan dari aplikasi yang dibuat.

7. Membuat laporan dari proses penelitian.

\subsection{Gambaran Umum Sistem}

Gambaran umum dari aplikasi yang akan dibangun adalah sebuah aplikasi berbasis Android sebagai media untuk pelaporan pelanggaran parkir yang memanfaatkan kamera smartphone agar dapat mengambil gambar kendaraan si pelanggar dan kemudian mengirimkan ke sisi server. Komponen utama dari sistem ini 
adalah 1) pengiriman data pelanggar, 2) pengelolaan data pelanggar, 3) pembuatan laporan dan surat tilang. Pengguna sistem pada alpikasi Android adalah masyarakat umum sedangkan pada web server adalah petugas DLLAJ. Pengguna aplikasi Android hanya dapat mengirimkan data pelanggaran pada web server. Sedangkan petugas DLLAJ mempunyai hak akses untuk mengelola data pelanggar, menindak lanjuti pelanggar dengan memberikan surat tilang, dan memblock atau unblock pengguna aplikasi Android apabila mengirimkan data yang tidak benar. Gambaran umum sistem pelaporan pelanggaran parkir dapat dilihat pada gambar 4.

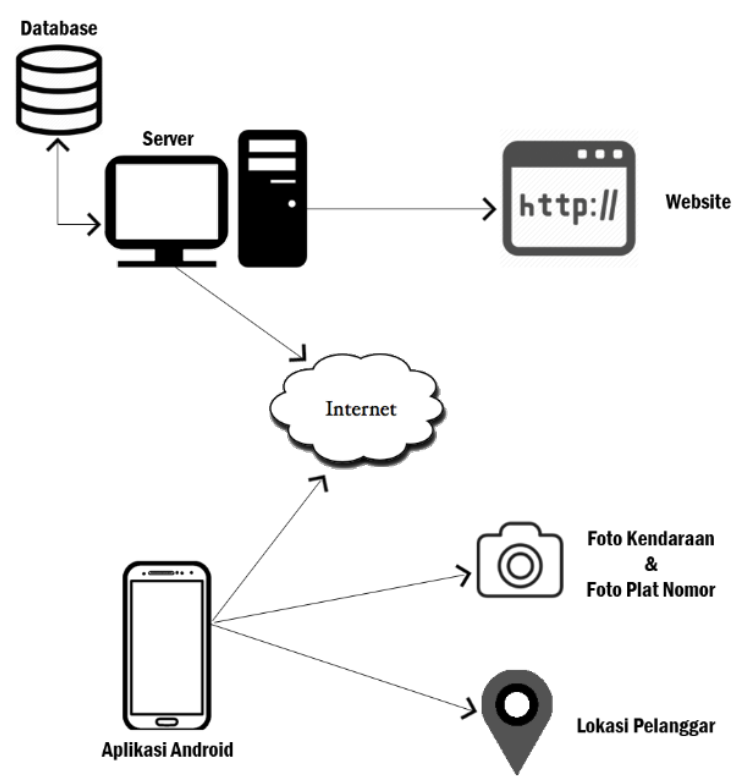

Gambar 4. Gambaran Umum Sistem Pelaporan Pelanggaran Parkir

\subsection{Use Case Diagram}

Use case diagram merupakan salah satu teknik yang digunakan untuk memperlihatkan interaksi antar pengguna sistem dengan sistem. Masing-masing use case terdapat aktor utama yang meminta sistem untuk memberi sebuah layanan. Aktor yang tujuannya akan dipenuhi oleh use case disebut dengan aktor utama. Selain itu terdapat beberapa aktor lain yang berinteraksi dengan sistem saat menjalankan use case [13]. Use Case Diagram dari sistem pelaporan pelanggaran parkir berbasis Android ditunjukkan pada gambar 5 .

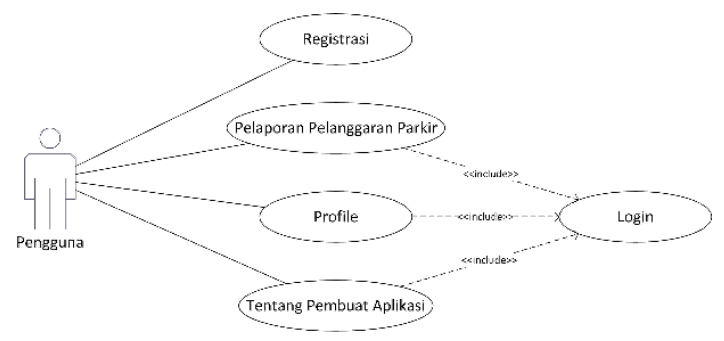

Gambar 5. Use Case Diagram

Pada gambar 5 menjelaskan pengguna yang berinteraksi dengan aplikasi pelaporan pelanggaran parkir. Dalam aplikasi terdapat 3 menu yaitu, pelaporan pelanggaran parkir, profile dan tentang pembuat aplikasi.

\subsection{Activity Diagram}

Dalam menggambarkan kegiatan (workflow) dari rancang bangun sistem pelaporan pelanggaran parkir, maka penelitian ini dibuat Activity Diagram seperti pada gambar 6 . 


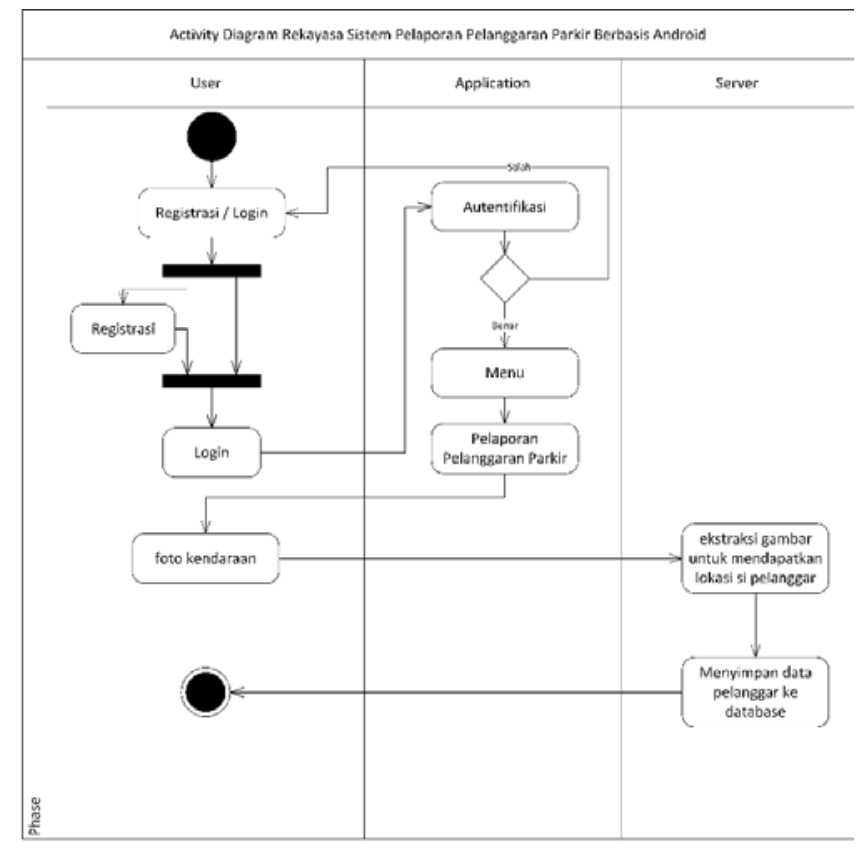

Gambar 6. Activity Diagram

Saat membuka aplikasi, pengguna diharuskan untuk login. Setelah berhasil login, maka pengguna akan masuk ke menu utama yaitu pelaporan pelanggaran parkir. Kemudian pengguna akan diminta untuk memasukkan plat nomor kendaraan dan mengambil beberapa gambar kendaraan yang melanggar. Langkah selanjutnya yaitu mengekstraksi gambar untuk mendapatkan koordinat latitude dan longitude. Langkah terakhir adalah menyimpan data pelanggar ke dalam database.

\subsection{Relasi Antar Tabel}

Relasi antar table adalah hubungan yang terdapat dalam satu tabel dengan tabel lain dimana hubungan tersebut mempresentasikan antar objek dan berguna untuk me-manage operasi suatu database seperti pada gambar 7 .
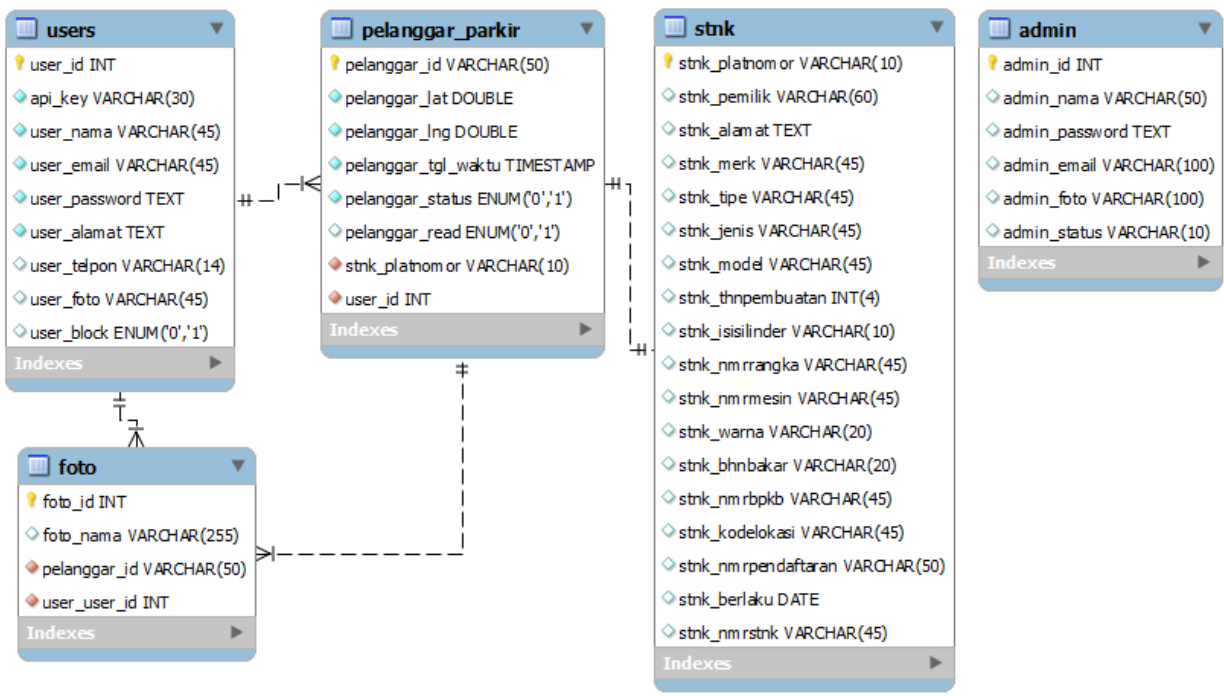

Gambar 7. Skema relasi antar tabel 


\section{HASIL DAN PEMBAHASAN}

\subsection{Hasil}

Hasil dari perancangan sistem pelaporan pelanggaran parkir berbasis Android ini adalah suatu aplikasi yang dapat digunakan oleh masyarakat umum untuk melaporkan pelanggaran parkir di bahu jalan. Aplikasi yang dibuat dapat memberikan kemudahan bagi masyarakat untuk melaporkan para pengendara kendaraan yang melanggar rambu larangan parkir. Dalam aplikasi ini terdapat fitur layanan informasi geografis yang bertujuan untuk mempermudah petugas DLLAJ untuk mengetahui lokasi pelanggaran parkir terjadi.

Dalam penelitian ini terdapat 2 sistem yang akan dibangun, yaitu aplikasi Android sebagai client dan aplikasi Web sebagai server.

\subsection{Pembahasan Ekstrak Metadata dari Foto}

Pada tahap ini akan dilakukan cara pengambilan metadata (latitude, longitude) dari sebuah foto. Untuk mempermudah penggunaan aplikasi, peneliti menggunakan sebuah fungsi untuk mengambil metadata dari foto yang dikirimkan dari sisi client ke server. Pada saat foto dikirim ke web server, maka fungsi ini akan memproses foto tersebut untuk mengambil nilai latitude dan longitude. Dengan menggunakan fungsi exif_read_data dari PHP, kita dapat mendapatkan metadata dari sebuah foto. Tidak hanya mendapatkan nilai latitude dan longitude saja, tetapi juga seluruh detail dari foto tersebut.

\subsection{Pembahasan Aplikasi Android \\ 4.3.1 Menu Login}

Menu login digunakan untuk dapat mengakses menu utama. Menu login ini terdapat pada halaman awal sisem, pada saat pengguna ingin menggunakan aplikasi pelaporan pelanggaran parkir, maka akan ditampilkan form login. Apabila pengguna belum memiliki akun, pengguna dapat melakukan registrasi pada halaman registrasi. Halaman login dan registrasi dapat dilihat pada gambar 8 .

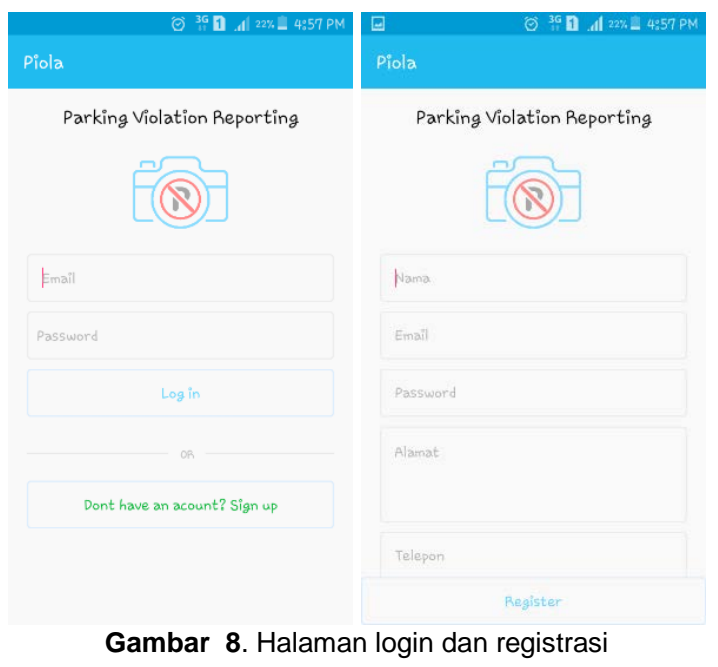

\subsubsection{Menu Pelaporan Pelanggaran Parkir}

Halaman ini merupakan halaman utama dari aplikasi. Saat pengguna berhasil login, maka secara otomatis pengguna akan diarahkan pada halaman pelaporan pelanggaran parkir. Didalam halaman ini terdapat beberapa input yang harus diisi oleh pengguna untuk melaporkan pelanggaran parkir, yaitu: plat nomor kendaraan, 5 foto bukti pelanggaran (minimal 2 foto). Kemudian terdapat tombol baca petunjuk yang berfungsi untuk memberikan intruksi terkait penggunaan aplikasi. Setelah semua inputan terisi, maka langkah terakhir yaitu menekan tombol submit untuk mengirim data ke server. Tampilan halaman pelaporan pelanggaran parkir dapat dilihat pada gambar 9 .

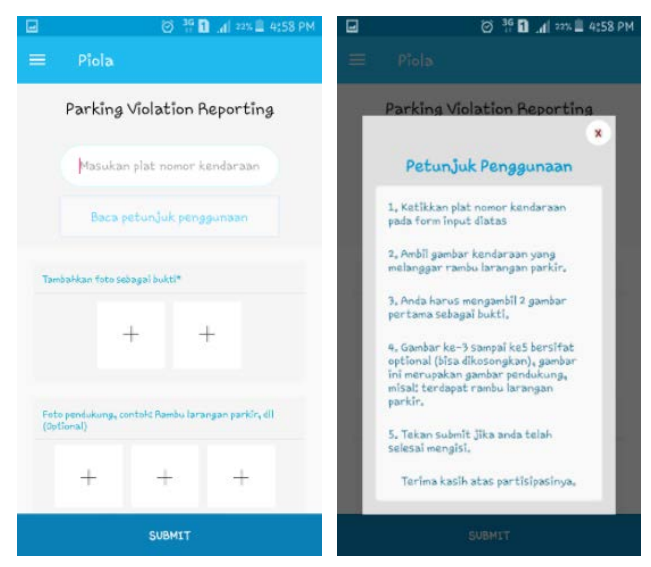

Gambar 9. Halaman Utama sistem 


\subsubsection{Menu Profile}

Halaman ini merupakan halaman profile pengguna. Pengguna dapat mengubah profile mereka seperti: nama, email, password, alamat dan nomor telpon. Tampilan profile pengguna dapat dilihat pada gambar 10.

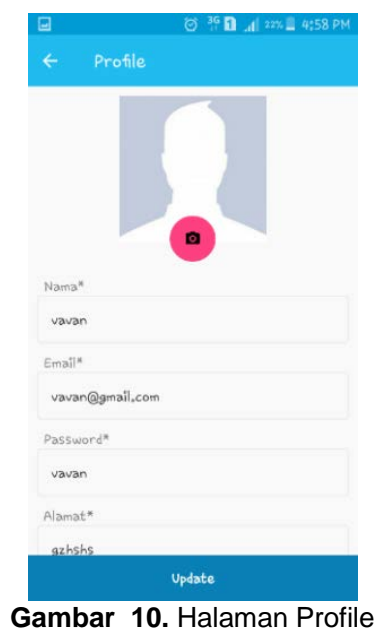

\subsection{Pembahasan Aplikasi Berbasis Website}

\subsubsection{Menu Login}

Halaman login merupakan portal untuk mengakses dashboard dari sebuah halaman admin. Form ini berisi nama pengguna dan password yang terlebih dahulu harus diisi oleh pengguna untuk dapat masuk kedalam dashboard. Tampilan Form login terdapat pada gambar 11 .

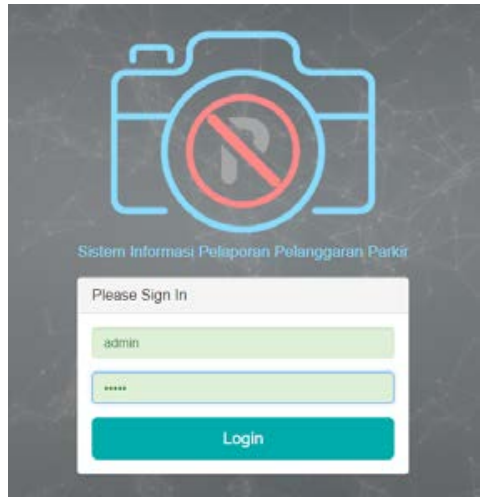

Gambar 11. Form Login

\subsubsection{Dashboard Admin}

Halaman ini akan ditampilkan pada admin apabila login telah berhasil. Pada halaman ini akan ditampilkan data mengenai pelanggaran parkir, administrator, Operator dan pengguna aplikasi Android sehingga admin dapat mengetahui jumlah pengguna aplikasi, jumlah Admin, Jumlah operator dan total pelanggaran yang terjadi. Pada bagian sidebar terdapat beberapa menu seperti Dashboard, Data users, Monitoring, Laporan, Pengguna aplikasi. Kemudian pada bagian top navigation terdapat notifikasi, profile admin, dan logout.

\subsubsection{Menu Monitoring}

Halaman ini akan menampilkan semua laporan pelanggaran parkir yang dikirimkan oleh pengguna aplikasi Android. Tampilan laporan pelanggaran parkir dapat dilihat pada gambar 12.

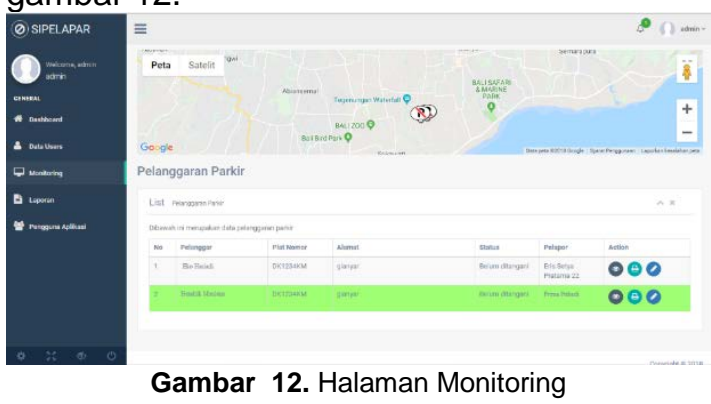

Pada gambar 12 terdapat Google
Maps View lengkap dengan marker (penanda). Marker berfungsi untuk menandakan bahwa adanya pelanggaran parkir di area tersebut. Kemudian terdapat tabel pelanggaran parkir yang berisi: Nama, Plat Nomor, Alamat, Status, Pelapor dan Action. Pada bagian action terdapat beberapa fungsi, yaitu: fungsi untuk melihat detail pelanggaran, fungsi untuk mencetak surat tilang online dan fungsi untuk mengubah (edit) data pelanggar. Untuk detail pelanggaran dapat dilihat pada gambar 13 , sedangkan cetak surat tilang dapat dilihat pada gambar 14 . 

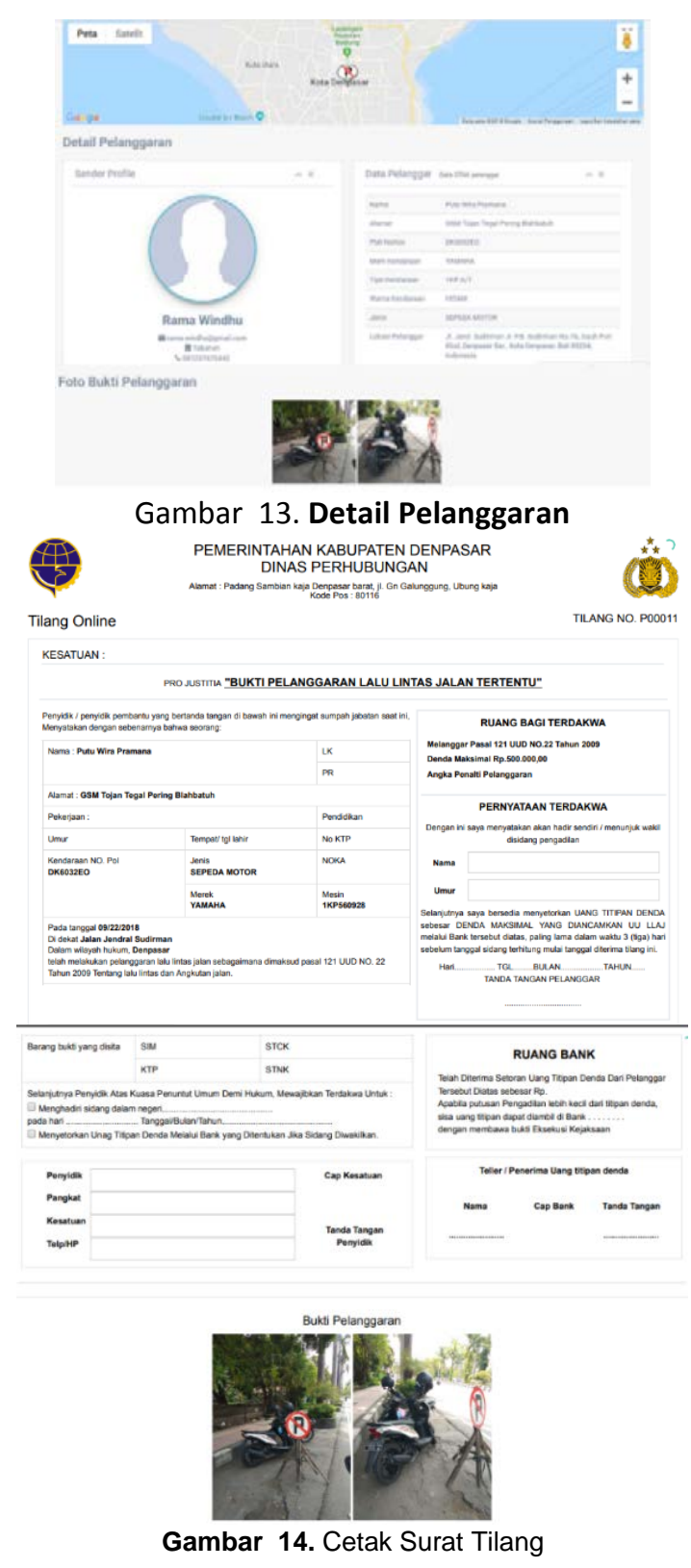

\subsubsection{Menu Pengguna Aplikasi Android}

Halaman ini merupakan halaman kontak pengguna aplikasi Android. Semua pengguna yang telah melakukan registrasi pada aplikasi Android akan ditampilkan pada halaman ini. Pada halaman ini juga terdapat fungsi untuk mem-block atau unblock pengguna Android apabila pengguna aplikasi mengirimkan data-data yang tidak benar. Halaman kontak pengguna dapat dilihat pada gambar 15.

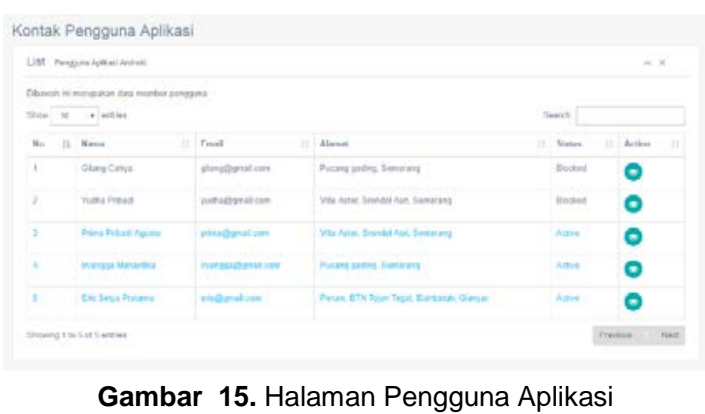

\subsection{Pengujian Sistem}

\subsubsection{Black Box Testing}

Pengujian Black Box dilakukan untuk menguji apakah sistem yang dikembangkan sesuai dengan spesifikasi fungsional sistem. Pengujian yang dilakukan yaitu berjumlah 23 fungsi. Salah satu pengujian dari Black Box Testing dapat dilihat pada table 1.

Tabel 1. Pengujian Black Box

\begin{tabular}{|l|l|l|}
\hline Nama Pengujian & Login \\
\hline Tujuan & Masuk kedalam sistem website \\
\hline Kondisi awal & Pengguna dalam halaman login website \\
\hline Skenario & \multicolumn{3}{|l|}{ Pengguna login pada sistem sebagai Admin atau Operator } \\
\hline Hasil & \multicolumn{3}{|l|}{ Yang diharapkan } & \multicolumn{1}{|c|}{ Pengamatan } & Kesimpulan \\
\hline Data yang diberikan & $\begin{array}{l}\text { Apabila berhasil login, } \\
\text { maka pengguna akan } \\
\text { diarahkan pada } \\
\text { dashboard dari sistem. } \\
\text { Apabila gagal, maka } \\
\text { terdapat peringatan }\end{array}$ & $\begin{array}{l}\text { Apabila berhasil login, } \\
\text { maka pengguna akan } \\
\text { diarahkan pada } \\
\text { dashboard dari sistem. } \\
\text { Apabila gagal, maka } \\
\text { terdapat peringatan }\end{array}$ \\
\hline
\end{tabular}

Hasil dari pengujian Black Box Testing, seluruh fungsionalitas pada aplikasi pelaporan pelanggaran parkir telah dinyatakan berhasil dijalankan sesuai dengan yang diharapkan.

\subsubsection{System Usability Scale (SUS)}

Pengujian SUS dilakukan dengan melibatkan 20 orang tester. Usability yang dilakukan meliputi learnability (fungsi dasar produk mudah dioperasikan), efficiency (fungsi produk dapat dengan cepat dipergunakan), memorability (setelah pengguna meninggalkan aplikasi dalam waktu lama, dapat dengan mudah untuk mengerti kembali), errors (seberapa banyak error yang terdapat pada produk) dan satisfaction (kepuasan pengguna). Hasil SUS dapat dilihat pada tabel 2 .

Tabel 2. Data responden SUS
\begin{tabular}{|c|c|c|c|c|c|c|c|c|c|c|}
\hline \multirow{2}{*}{$\begin{array}{c}\text { Respon- } \\
\text { den }\end{array}$} & 1 & 2 & 3 & 4 & 5 & 6 & 7 & 8 & 9 & 10 \\
\cline { 2 - 8 }
\end{tabular}




\begin{tabular}{|c|c|c|c|c|c|c|c|c|c|c|}
\hline 1 & 5 & 3 & 5 & 3 & 5 & 1 & 5 & 1 & 5 & 5 \\
\hline 2 & 5 & 1 & 5 & 1 & 5 & 1 & 5 & 1 & 5 & 1 \\
\hline 3 & 5 & 5 & 5 & 3 & 5 & 2 & 4 & 1 & 4 & 5 \\
\hline 4 & 5 & 2 & 4 & 1 & 4 & 1 & 4 & 1 & 4 & 5 \\
\hline 5 & 5 & 5 & 5 & 4 & 5 & 3 & 5 & 3 & 5 & 4 \\
\hline 6 & 5 & 2 & 5 & 1 & 5 & 1 & 5 & 1 & 5 & 1 \\
\hline 7 & 4 & 2 & 4 & 2 & 4 & 3 & 4 & 4 & 3 & 3 \\
\hline 8 & 3 & 2 & 4 & 1 & 3 & 2 & 4 & 1 & 5 & 1 \\
\hline 9 & 4 & 2 & 5 & 1 & 3 & 2 & 4 & 1 & 3 & 1 \\
\hline 10 & 3 & 3 & 4 & 2 & 3 & 2 & 4 & 3 & 3 & 2 \\
\hline 11 & 5 & 1 & 5 & 1 & 5 & 1 & 5 & 1 & 5 & 1 \\
\hline 12 & 3 & 2 & 4 & 1 & 3 & 2 & 4 & 2 & 3 & 3 \\
\hline 13 & 4 & 2 & 4 & 1 & 4 & 1 & 5 & 1 & 4 & 1 \\
\hline 14 & 5 & 2 & 5 & 1 & 4 & 2 & 5 & 5 & 5 & 1 \\
\hline 15 & 5 & 1 & 5 & 1 & 5 & 1 & 5 & 1 & 5 & 1 \\
\hline 16 & 5 & 4 & 4 & 3 & 4 & 1 & 3 & 1 & 5 & 1 \\
\hline 17 & 3 & 1 & 5 & 1 & 3 & 4 & 5 & 2 & 4 & 1 \\
\hline 18 & 4 & 2 & 5 & 1 & 3 & 3 & 4 & 2 & 4 & 1 \\
\hline 19 & 5 & 4 & 4 & 3 & 4 & 2 & 4 & 2 & 4 & 3 \\
\hline 20 & 5 & 2 & 5 & 2 & 4 & 2 & 4 & 2 & 4 & 2 \\
\hline
\end{tabular}

Tahap selanjutnya adalah mengkonversi skala nilai dari pernyataan tiap-tiap responden. Data yang telah dikonversikan dapat dilihat pada tabel 3 .

Tabel 3. Data responden SUS yang telah dikonversi

\begin{tabular}{|c|c|c|c|c|c|c|c|c|c|c|c|c|}
\hline \multirow{2}{*}{$\begin{array}{c}\text { Respo- } \\
\text { nden }\end{array}$} & 1 & 2 & 3 & 4 & 5 & 6 & 7 & 8 & 9 & 10 & \multirow{2}{|c|}{$\begin{array}{c}\text { Hasil } \\
\text { dikali } \\
2,5\end{array}$} \\
\hline 1 & 4 & 2 & 4 & 2 & 4 & 4 & 4 & 4 & 4 & 0 & 32 & 80 \\
\hline 2 & 4 & 4 & 4 & 4 & 4 & 4 & 4 & 4 & 4 & 4 & 40 & 100 \\
\hline 3 & 4 & 0 & 4 & 2 & 4 & 3 & 3 & 4 & 3 & 0 & 27 & 67,5 \\
\hline 4 & 4 & 3 & 3 & 4 & 3 & 4 & 3 & 4 & 3 & 0 & 31 & 77,5 \\
\hline 5 & 4 & 0 & 4 & 1 & 4 & 2 & 4 & 2 & 4 & 1 & 26 & 65 \\
\hline 6 & 4 & 3 & 4 & 4 & 4 & 4 & 4 & 4 & 4 & 4 & 39 & 97,5 \\
\hline 7 & 3 & 3 & 3 & 3 & 3 & 2 & 3 & 1 & 2 & 2 & 25 & 62,5 \\
\hline 8 & 2 & 3 & 3 & 4 & 2 & 3 & 3 & 4 & 4 & 4 & 32 & 80 \\
\hline 9 & 3 & 3 & 4 & 4 & 2 & 3 & 3 & 4 & 2 & 4 & 32 & 80 \\
\hline 10 & 2 & 2 & 3 & 3 & 2 & 3 & 3 & 2 & 2 & 3 & 25 & 62,5 \\
\hline 11 & 4 & 4 & 4 & 4 & 4 & 4 & 4 & 4 & 4 & 4 & 40 & 100 \\
\hline 12 & 2 & 3 & 3 & 4 & 2 & 3 & 3 & 3 & 2 & 2 & 27 & 67,5 \\
\hline 13 & 3 & 3 & 3 & 4 & 3 & 4 & 4 & 4 & 3 & 4 & 35 & 87,5 \\
\hline 14 & 4 & 3 & 4 & 4 & 3 & 3 & 4 & 0 & 4 & 4 & 33 & 82,5 \\
\hline 15 & 4 & 4 & 4 & 4 & 4 & 4 & 4 & 4 & 4 & 4 & 40 & 100 \\
\hline 16 & 4 & 1 & 3 & 2 & 3 & 4 & 2 & 4 & 4 & 4 & 31 & 77,5 \\
\hline 17 & 2 & 4 & 4 & 4 & 2 & 1 & 4 & 3 & 3 & 4 & 31 & 77,5 \\
\hline 18 & 3 & 3 & 4 & 4 & 2 & 2 & 3 & 3 & 3 & 4 & 31 & 77,5 \\
\hline 19 & 4 & 1 & 3 & 2 & 3 & 3 & 3 & 3 & 3 & 2 & 27 & 67,5 \\
\hline & & & & & & & &
\end{tabular}

\begin{tabular}{|l|l|l|l|l|l|l|l|l|l|l|l|l|}
20 & 4 & 3 & 4 & 3 & 3 & 3 & 3 & 3 & 3 & 3 & 32 & 80 \\
\hline
\end{tabular}

Dari hasil konversi data pengujian system usability scale (SUS), didapatkan nilai rata-rata sebesar 79,5. Dengan demikian dapat disimpulkan bahwa nilai SUS berada di atas rata-rata dan aplikasi pelaporan pelanggaran parkir dinyatakan dapat diterima (acceptable) oleh pengguna.

\section{SIMPULAN}

\subsection{Simpulan}

Berdasarkan hasil pembahasan dalam pemanfaatan sistem pelaporan pelanggaran parkir berbasis Android, maka diperoleh simpulan sebagai berikut:

1. Aplikasi pelaporan pelanggaran parkir dirancang dengan menggunakan Android Studio memiliki fitur lengkap sehingga aplikasi pelaporan menjadi lebih menarik dan mudah untuk digunakan oleh pengguna.

2. Pengujian Black Box Testing menunjukkan seluruh fungsionalitas dari aplikasi yang telah dibangun dapat berjalan dengan baik sesuai dengan yang diharapkan,

3. Hasil pengujian System Usability Scale (SUS) responden memberikan skor ratarata sebesar 79,5 yang berarti hasil pengujian memiliki nilai di atas rata-rata sehingga aplikasi dinyatakan dapat diterima (acceptable) dan berjalan dengan baik pada smartphone Android.

\section{DAFTAR PUSTAKA}

[1] D. Praditya, Pemanfaatan Teknologi dan Komunikasi (TIK) di Tingkat Pemerintahan Desa, Bandung, 2014.

[2] Suhariyanto, A. Lumaksono, M. Ari Nugraha and M. Sairi, "Badan Pusat Statistik," Badan Pusat Statistik web site, 14 December 2016. [Online]. Available:

https://www.bps.go.id/linkTableDinamis /view/id/1133. [Accessed 25 September 2018].

[3] A. B. Tejo, Undang-Undang Republik Indonesia Nomor 22 Tahun 2009 Tentang Lalu lintas dan angkutan jalan, Jakarta: PT Justika Siar Publika, 2009.

[4] M. G. Nastiar, "Sistem Pelaporan 
Kerusakan Jalan pada Bina Marga Makasar Berbasis Web dan Mobile," 2016.

[5] F. Masya, Elvina and M. F. Simanjuntak, "Sistem Pelayanan Pengaduan Masyarakat pada Divisi Humas Polri Berbasis WEB," Seminar Nasional Aplikasi Teknologi Infoormasi, 2012.

[6] S. Mulyono and D. Dwijono, "Implementasi metadata simple dublin core dalam pembangunan program pengarsipan data studi kasus himpunan mahasiswa prodi sistem informasi universitas kristen duta wacana," EKSIS, pp. 84-94, 2014.

[7] H. Kristiandi, "Pembangunan Aplikasi Pencarian Persewaan Lapangan Futsal di Yogyakarta Berbasis Lokasi," Yogyakarta, 2014.

[8] J. Brooke, "SUS - A quick and Dirty Usability Scale," in Usability Evaluation In Industry, Earley, READING, CRC Press, 1996, pp. 189-194.

[9] A. Bangor, P. T. Kortum and J. T. Miller, "An Empirical Evaluation of the System Usability Scale," Int. J. Hum. Comput. Interact., vol. 24, no. 6, pp. 574-594, 2008.

[10] A. Bangor, P. T. Kortum and J. T. Miller, "Determining what individual SUS scores mean: adding an adjective rating scale," Journal of Usability Studies, vol. 4, no. 3, pp. 114-123, 2009.

[11] M. Fowler, UML Distilled Edisi 3, Yogyakarta: Andi, 2005.

[12] B. Sidik, Pemrograman Web PHP, Bandung, 2014.

[13] M. S. Mustaqbal, R. F. Firdaus and H. Rahmadi, "Pengujian Aplikasi Menggunakan Black Box Testing Boundary Value Analysis (Studi kasus: Aplikasi Prediksi Kelulusan SNMPTN)," Jurnal IImiah Teknologi Informasi Terappan, pp. 31-36, 2015. 